\title{
Aspects of higher education and black chartered accountants: empirical findings
}

\author{
E Sadler \\ University of South Africa
}

\begin{abstract}
A shortage of black people in the accounting profession in South Africa is a major cause for concern. The South African Institute of Chartered Accountants set itself a target of 3000 black chartered accountants by 2005. Currently there are only about 245

This article is based on the results of a survey among black chartered accountants in South Africa. The purpose of the article is to furnish insight into the reasons why so few blacks have chosen to study accountancy, particularly on a postgraduate level and the problems they experi enced whilst studying towards the chartered accountancy qualification. The accounting pro fession, business, institutions of higher educa tion and black students should work together in order to make a significant contribution towards integrating blacks into the accounting profes sion.
\end{abstract}

\section{INTRODUCTION}

$\mathbf{I}^{\mathrm{n}}$ its latest report, the Human Sciences Research Council (HSRC 1999:48) identified chartered accountancy as a "super growth" occupation, with an expected growth of more than $40 \%$. According to the researchers, the profession was showing strong growth and also its business was becoming increas ingly complex in nature, necessitating the substitution of lower level staff such as clerks for professionally trained personnel.

A very important dimension of the skills shortage problem that was identified was the lack of highly skilled black South Africans. Approximately one tenth of the organisations that were surveyed referred to the difficulties involved in recruiting black managers and professionals. The researchers concluded that the previous exclusion of blacks from professional and managerial positions was having a serious effect on the availability of skills (HSRC 1999:118 120).

A shortage of black people in the accounting profession in South Africa is a major cause for concern. Only 207 (ie, a mere 1,06\%) of the total number of 19493 chartered accountants (CAs) registered with the South African Institute of Chartered Accountants (SAICA) are black. This means that their numbers have increased by $170 \%$ since 1994, when there were only 77 black CAs in South Africa. To address this imbalance, SAICA in 1998 set itself a target of 3000 black CAs by 2005 that is, by 2005, 25\% of all CAs in South Africa should be black.

The Qualifying Examination (QE), which, when passed, gives entrance to the accountancy profession, is taken after students have passed the Certificate in the Theory of Accountancy (CTA), offered by accredited universities in South Africa.

In 1999, SAICA introduced a new examination system for prospective chartered accountants. The $\mathrm{QE}$ is now taken in two parts. The purpose of Part I of the $\mathrm{QE}$ is to test the integrated application of cognitive knowledge, preferably as soon as possible after the prescribed academic requirements have been met. Under the new system, candidates may enter for the Part II examination only after having served 18 months of a recognised training contract, and after having completed a recognised auditing or financial management specialist course. These courses are conducted while in training and help the candidates integrate practical experience with theory. One reason for implementing the new system was that students can now better focus on each part of the examination at the appropriate time in their

Contact person

Prof E Sadler, Dept of Applied Accountancy, University of South Africa, PO Box 392, Unisa, 0003

Tel (012) $4294737 / 4305 / 4404 / 4357$

Fax (012) 4294658

e mail sadlee@unisa ac za 
career development. SAICA believed that this would result in a better pass rate in the longer term, which would help the Institute achieve its objective of overcoming the shortage of CAs, especially black CAs, in South Africa.

In 2000, the Part 1 pass rate for blacks reflected a significant increase of almost $50 \%$ (the pass rate was $44 \%)$, as compared with previous years, when the pass rate was around $30 \%$. However, the pass rate was still much lower than the national pass rate of 64\% (Mabenar 2000:3). In 2001, the Part 1 pass rate for black candidates was $34,6 \%$, as against the national pass rate of $61 \%$. In that year, 107 black candidates passed. In November 2001, 71 blacks passed Part 2 of the examination. Whilst the number of black candidates are increasing and their pass rates are also improving, it is doubtful whether the target set will be reached.

In 2000, the Equity Development and the Education and Training Departments of SAICA merged into a single new entity, the Accountancy Development Unit. The mission of the Unit is to facilitate the transformation in the education and training of prospective CAs, in order to ensure the development of blacks/females and their integration into the profession, thereby supporting economic develop ment in South Africa (SAICA 2001:3). The Unit is responsible for, inter alia, initiating or assisting with various equity development projects which will help SAICA achieve an accountancy profession that is demographically representative in nature.

In 2002, SAICA launched a five year, R62 million education project, called Thuthuka, to increase the number of black CAs. The first prong involves improving the maths and accounting skills of 6400 Grade 12 and high schoolgoers in the Eastern Cape via mathematics and accounting clinics.

The second prong is an alliance between the University of Fort Hare and the Rand Afrikaans University to improve the quality of the BCom accounting degrees awarded by Fort Hare through an intensive combination of tutorials and tuition.

The third prong in Thuthuka's programme involves teaching the community personal finance everything from balancing household budgets to teaching princi pals to manage their schools' budgets (Lipson 2002:5).

\section{PROBLEM STATEMENT}

From informal discussions with accounting aca demics and professionals it is apparent that it is doubtful that the target of 3000 black CAs by 2005 will be reached. In order to help the profession reach this target it appears to be necessary, as a first step, to obtain information from the present 207 black CAs in South Africa on the following issues:

- why such a small number of blacks choose to study accountancy

- why black accounting students do not study accountancy on a post graduate level

- why these black CAs chose to study accountancy

- problems experienced by black CAs whilst study ing towards the CA qualification

- the implications of the above for SAICA and the profession at large.

\section{RESEARCH METHODOLOGY}

\section{Statistical procedures}

The Statistical Analysis System (SAS) program was used to perform the data analysis. The following calculations were performed, using the program:

- frequency distributions

- reliability tests (cronbach coefficient) (80\% relia bility was achieved)

- T tests

- cross tabulation and chi square calculations at a $0,05 \%$ and $0,01 \%$ significance level, with the following dependent variables:

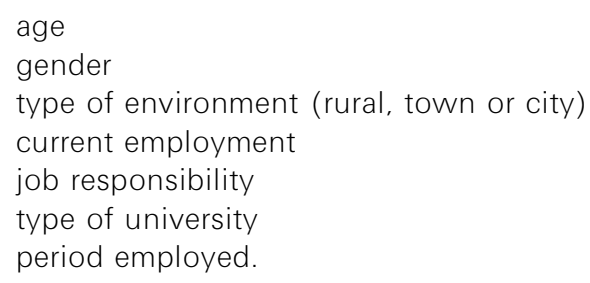

\section{The questionnaire}

The questionnaire was designed by drawing on the literature (for example Hammond \& Streeter 1994; Mitchell et al 1990; Moyes et al 2000; Ward et al 1994) to determine the issues to be addressed. The questionnaire was piloted with a sample of 20 respondents.

The questionnaire had seven sections, namely:

- Personal details

- Employment details

- Education

- Work environment

- Job satisfaction

- Career goals and intentions

- General (eg their views on the role of blacks in the profession).

\section{Sampling}

The survey was conducted in May 2001, with 207 questionnaires being mailed to all the black CAs in 
South Africa. The questionnaires were accompanied by a covering letter, mentioning the support of the SAICA and ABASA. A letter, signed by Mr Southie Gounden, President of ABASA, wherein he expressed his organisation's co operation of the research pro ject, also accompanied the questionnaires. The cover ing letter explained the purposes of the research and encouraged participation. A single follow up mailout was carried out three weeks later.

A total of 69 usable responses were received, representing a remarkable response rate of $33 \%$.

\section{RESULTS AND DISCUSSION}

\section{General profile}

This survey proved to give a very representative profile of the black SAICA membership as a whole. About a third of the respondents were younger than 30 years of age which is indicative of the increasing number of blacks that entered the profession in recent years. Nineteen percent of the respondents were female. Half the respondents had grown up in a rural environment, and $27 \%$ and $23 \%$ in a town or a city respectively. Fifty four percent of the respondents were employed in commerce and industry, as against the only $33 \%$ employed in public practice. Seven percent were employed by Government. Fifty two percent of the respondents had left public practice for better opportunities elsewhere, and a further $11 \%$ said they had left because of a lack of advancement in public practice.

\section{The educational background of black CAs in South Africa}

The questionnaire contained questions about the educational background of black CAs. The following constitutes a short summary of its findings.

Six of the respondents had master's degrees, 55 had honours degrees, and seven had bachelor's degrees. Fifty percent of the respondents had registered with SAICA by the age of 27 , and $78 \%$ by the age of 30 . The youngest respondent to register was 21 years old. and another 15 respondents had registered by the age of 25 .

Since most students completed their secondary school education by the age of 18 it means that $24 \%$ of the respondents obtained their CA qualifica tion within seven years after leaving school. A full time student can qualify in a minimum of seven years, and a part time student may qualify in as short a period as five years. In this study, most respondents indicated that they had studied on a full time basis. These results show that almost a quarter of the respondents had passed the QE at a reasonably young age.

Historically, the pass rate of black candidates in the QE was much lower than that of the other racial groups. In this study, $64 \%$ of the respondents had passed Part 1 of the QE with their first attempt, and only $42 \%$ had passed Part 2 of the examination with their first attempt. The national pass rate for students who took Part 1 of the QE for the first time in 2001 was $66 \%$ (as against $71 \%$ in 2000), whereas the pass rate for students who took Part 2 of the examination for the first time in 2000 was $69 \%$.

The majority (57\%) of the respondents had obtained their CTA at Unisa. In 2000, 44\% of Unisa's student population was black. In the same year, a total of 723 black students were registered for the Hons BCompt (CTA) qualification at that university. Over the past years, Unisa had produced the highest number of candidates to pass the QE namely $24 \%$ of the total number of students registered for that qualification.

However, in 2000 only 68 (9\%) of the black students passed the Hons BCompt (CTA) examination, and only $20(29 \%)$ of those passed Part 1 of the QE, whereas $76 \%$ (577) of the white students passed the Hons BCompt (CTA) in the same year, and $54 \%$ of those passed Part 1 of the OE. Therefore, out of a total of 723 black students who were registered at Unisa for their final year of studies only 20 (2,8\%) passed Part 1 of the QE in 2001

Relatively few black students qualify for university entrance because they tend not to focus on mathe matics in their school curriculum (Africa News Service:2000). Collier and McGowan (1989) pro vided anecdotal evidence according to which students who do well in accounting seem to understand number concepts. They hypothesised that a minimum competency in arithmetic and algebra is necessary, but not sufficient, for success in an academic accounting programme. Gist et al (1996:49 60) investigated the extent to which mathematical skills had an influence on the perfor mance of black students in accounting classes. They found that black students with higher grades in mathematics tended to perform better in accounting coursework. They suggested that individuals con cerned with advising and admitting black students interested in accounting should take these grades into consideration.

The respondents in this study were asked to indicate their matric symbols for English, mathematics and accounting, the results which are shown in Table 1. 
Table 1

Matric symbols obtained by black CAs

\begin{tabular}{|c|c|c|c|c|c|c|}
\hline Symbol & English & $\%$ & Maths & $\%$ & Accounting & $\%$ \\
\hline A & 2,9 & & 7,3 & & 5,8 & \\
\hline B & 13,0 & 53,6 & 13,0 & 37,7 & 14,5 & 36,2 \\
\hline C & 37,7 & & 17,4 & & 15,9 & \\
\hline $\mathrm{D}$ & 21,7 & & 26,1 & & 7,3 & \\
\hline E & 11,6 & & 14,6 & & 1,5 & \\
\hline $\mathrm{F}$ & 1,5 & & 5,8 & & & \\
\hline Had not taken the subject & & & & & 55,0 & \\
\hline No answer & 11,6 & & 15,9 & & & \\
\hline & $100 \%$ & & $100 \%$ & & $100 \%$ & \\
\hline
\end{tabular}

Table 1 shows that only $37,7 \%$ of the respondents had obtained an A, B or C symbol for mathematics, and that only $36,2 \%$ had obtained an $\mathrm{A}, \mathrm{B}$ or $\mathrm{C}$ for accounting. More than 50\% had obtained such symbols for English. Surprisingly, 55\% of the respon dents had not even taken accounting as a subject at school. However, as is shown in Table 2, although many had not been encouraged to take accountancy as a subject at school, that was not the reason why there had previously been such a small number of black CAs.
Almost $50 \%$ of the fathers of the respondents had a Grade 8 qualification or lower.

\section{Why there had previously been such a small number of black CAs}

According to a survey by Mitchell and Flintall (1990:59 69) in the USA the main reasons for blacks not choosing accountancy as a career were the following:

Table 2

Why there had previously been such a small number of black CAs

\begin{tabular}{|l|c|}
\hline & $\%$ \\
\hline 1. Lack of career guidance & 84,06 \\
\hline 2. Lack of knowledge about the profession at school & 71,01 \\
\hline 3. Lack of role models in the profession & 59,42 \\
\hline 4. Lack exposure to business & 56,52 \\
\hline 5. Lack of funding and bursaries & 49,28 \\
\hline 6. Poor academic standards at school & 47,83 \\
\hline 7. Unable to get articles & 40,58 \\
\hline 8. Lack of teachers in Commerce and Mathematics & 37,68 \\
\hline 9. Racial discrimination & 34,78 \\
\hline 10. Not encouraged to take accountancy at school & 30,43 \\
\hline 11. Employer prejudice & 11,59 \\
\hline 12. Accountancy considered to be a "white occupation" & 10,14 \\
\hline 12. Instability in the community & 10,14 \\
\hline 13. Length of initial training & 7,25 \\
\hline
\end{tabular}


racial bias

lack of upward mobility

lack of strong affirmative action

lack of awareness of career opportunities.

Respondents in this study were asked why, in their view, there had previously been such a small number of black CAs. The following (see Table 2) are the main reasons that were given:

1. Lack of career guidance (84\%)

2. Lack of knowledge about the profession at school (71\%)

3. Lack of role models in the profession (59\%)

4. Lack of exposure to business (57\%)

5. Lack of funding and bursaries (49\%)

\section{Lack of career guidance and knowledge about the profession}

Mabena (1997:7), the Equity Development Officer of SAICA at the time, identified a lack of knowledge about the chartered accountancy profession and careers related to the profession in the black commu nity as one of the main reasons why previously there had been such a small number of blacks in the profession. In this study $84 \%$ of the respondents said that the main reason for the small number of blacks in the profession was a lack of career guidance in schools.

Career guidance counsellors have a great deal of influence as far as students' early career decisions are concerned. SAICA (Africa News Service 2000) also stated that the Institute was aware of the fact that teachers do not encourage their best students to study accountancy, and that that was the reason for the Institute forming a teachers' enrichment project. The recruitment officer of a "Big 5" accounting firm in South Africa who visited schools nationally to promote the profession said the following in a recent newspaper report: "Especially in black schools there is little awareness of the profession" (Fontyn 2001:6).

In the USA doctors and lawyers enjoy a more glamorous image among black scholars than CPAs. While many CPAs are financially more successful than doctors and lawyers this is not widely perceived to be the case, and being a CPA is not viewed as glamorous (Panel Discussion 1999:22).

The accounting profession in South Africa therefore needs to reach out to black schools and to institutions of higher education and "sell" the profession to them as challenging and interesting.

\section{Lack of role models}

Almost 60 per cent of the respondents felt that the lack of role models in the profession was one reason why there had previously been such a small number of black CAs. According to a report in the Financial Mail (1999:75), the fact that young black CAs are poached by government and the private sector also causes accounting firms to be unable to develop role models nor can they show that they are developing people through the system. Since there are only a few black CAs many black trainees have never seen or met a qualified black accountant. Role models are needed to create interest in the profession. "We need CPAs (whether practising as such or not) to be out in the communities as role models so that young people can see the rewards of a CPA career" (Panel discussion 1999:19)

Moyes et al (2000:44) explained that when gender discrimination became an issue the task of increasing female representation within the firms was a less daunting one. There were already many women in higher education. In order to increase the number of women entering the profession it was simply a matter of persuading them to select accounting as their major course of study. Also, current generations of women could frequently look to their own families (eg. mothers, fathers, older sisters and brothers) for examples of individuals who were successfully pursuing a career in business.

In most cases, black people are in a different situation. Frequently, incentives, encouragement and financial aid is necessary for many members of those black groups to continue their studies beyond secondary education. Often those who continue studying are the first generation in their family to attend an institution of higher education. Also, there are not enough role models to show that minorities can be successful in business.

In South Africa, CAs therefore need to be visible in the communities so that young people may see how rewarding a CA career can be.

\section{Lack of exposure to business}

More than half the respondents blamed lack of exposure to business as another reason for black students not choosing chartered accountancy as a career. Almost half the respondents had grown up in a rural environment in which young people are normally not exposed to a business environment and business people.

Effective communication and interpretation of infor mation often determines success in both the class room and the business community. In order to successfully complete business and accounting courses a student should have at least a basic grasp of the terminology used in business. Many of these basic business and accounting terms crop up in 
common business transactions, and also in everyday life.

Lecturers frequently assume that all students have a similar, if not an equal, understanding of business terms (Ward et al 1994:267), and yet students may have varying educational and personal circumstances, such as educational background (eg, black students in the "old" South Africa), social and economic status and ethnic origin. Often black students in South Africa have only a minimal academic high school background.

Often also, many black students have not even had minimal opportunities for exposure to the most basic business or economic experiences (Ward et al 1994:267; Cameron 1989:269 279). Ward et al 1994:272) concluded from their study among black students that there is a pronounced correlation between black students' business vocabulary skills and their academic achievement in university stu dies.

\section{Lack of funding and bursaries}

Fontyn (2001:6) reported the fact that many black CA candidates are financially disadvantaged, and also disadvantaged in terms of everyday logistics such as travel and access to computer technology. SAICA's examination officer, Angela Vest Louw, says that black candidates sometimes lack confidence because of those disadvantages.

Most black trainee accountants experience consider able financial pressure from their families upon completion of their studies. In many instances families made great sacrifices to put them through their studies and cannot afford further support for postgraduate studies. Also, there is a general expec tation of a return on investment from students who are now in a position of earning potentially good salaries (Memani 1994:25).

The fifth most important reason for not choosing a career in accountancy was said to be a lack of funding and bursaries. In the future, this will hopefully not be a major obstacle, as most of the "Big 5" auditing firms in South Africa nowadays allocate large sums of money as bursaries for aspiring black CAs.

Reasons that were considered least important for blacks not choosing accountancy as a career were the following:

1. Length of initial training (7\%)

2. Accountancy considered to be a white occupa tion $(10 \%)$

3. Instability in the community (10\%)

4. Employer prejudice (12\%)
5. Not encouraged to take accountancy at school (30\%)

\section{Why black accounting students do not study accountancy on a postgraduate level}

Respondents were asked to indicate the main reason, in their opinion, why black students do not study accountancy on a postgraduate level.

Fifty percent of the respondents believed the main reason to be lack of financial support and low salaries during the traineeship years. A further 29 per cent of the respondents said that because most blacks are expected to help support their families they cannot afford the luxury of postgraduate studies they have to earn a decent income as soon as possible. Three respondents had the following to say:

The need to support family members makes an added period of study and low remuneration during the traineeship (articles) an unattractive proposition.

Financial difficulties, since the traineeship period (articles) pay little and most blacks are expected to help their parents support their families giving them their daily bread and educating other siblings in the family.

The pressure either to financially support one's family or to be financially independent ... greater than the prospects of pursuing accounting to CA(SA) level.

More than 20\% also attributed the lack of progress to poor academic standards in secondary schools and at traditionally black universities. Other reasons given were the following:

1. Lack of support programmes $(9,7 \%)$

2. Lack of exposure to practical business matters $(8,1 \%)$

3. Discrimination in a predominantly white profes sion $(8,1 \%)$

\section{Reasons for choosing to study accountancy}

Prospective employers are often interested in why an employee chose a certain career. Respondents were asked their reasons for choosing a career in accoun tancy, and to say which factors had influenced their choice. In their survey among black CPAs Mitchell and Flintall (1990:59 64) identified characteristics of the profession that contribute to the respondents' decision to choose accounting as a career. They listed the following in order of importance:

- Intellectual challenges

- Opportunity for advancement 
Table 3

Reasons for choosing a career in accountancy

\begin{tabular}{|l|c|c|}
\hline \multicolumn{1}{|c|}{ Factor } & $\begin{array}{c}\text { \% of } \\
\text { respondents }\end{array}$ & Ranking \\
\hline Prestige of the profession & 63,77 & 1 \\
\hline Career prospects & 63,77 & 1 \\
\hline Salary potential & 57,97 & 2 \\
\hline Intellectual challenge & 46,38 & 3 \\
\hline Aptitude for working with numbers & 37,68 & 4 \\
\hline Enjoyed accountancy at school & 36,23 & 5 \\
\hline Security & 30,43 & 6 \\
\hline Interesting work & 26,64 & 7 \\
\hline Wanted a specialist business background & 18,84 & 8 \\
\hline Family member or friend is/was an accountant & 11,59 & 9 \\
\hline Parents encouraged me & 10,14 & 10 \\
\hline Career adviser or school career counsellor encouraged me & 10,14 & 10 \\
\hline Could study part time studies & 4,35 & 11 \\
\hline Potential for full or part time work from home & 2,90 & 12 \\
\hline
\end{tabular}

- Income level

- Prestige.

Four items were mentioned by 40 per cent or more of the respondents to this survey (see Table 3). They were in order of importance:

- Prestige of the profession

- Career prospects

- Salary potential

- Intellectual challenge.

Other important factors were the following: they had enjoyed accountancy as a subject at school, an aptitude for working with numbers, and new jobs were always available. A significant feature was the very small part played by career advisers, parents and family members, again indicating the absence of a positive recruitment effort.

\section{Problems whilst studying}

Both business in general and the accounting profes sion in particular show active progression towards increased black participation in the profession in this country. However, effective solutions can be imple mented only once the factors inhibiting black stu dents from successfully completing their studies have been understood
This research project tried to identify problems experienced by black CA candidates.

Table 4 shows that more than 50 per cent of the respondents identified the following as major pro blems whilst studying towards the CA qualification. No significant differences on a 95 per cent confidence level came to the fore as far as age groups and male and female respondents were concerned:

- Tests, assignments and examinations had to be taken in English (only 4\% of the respondents felt that this had posed no problem to them, and 69\% said that it had been a major problem).

- Little support from the employer with regard to studies (again, only 5\% said that this had not posed a problem)

- Their working environment had not been condu cive to effective learning (there was a very significant difference at a reliability level of one percent among respondents as far as their current employment was concerned.) Almost 70 per cent of those employed in business regarded this as a major problem, as against only 40 per cent of those in public practice who thought that this was a major problem.

- Poor level of training in accounting at school. (51\% regarded this as a major problem, and $21 \%$ regarded this as a minor problem). 
Table 4

Problems experienced by black CAs whilst studying towards the CA qualification

\begin{tabular}{|l|c|c|c|}
\hline \multicolumn{1}{|c|}{ Possible problems } & \multicolumn{2}{c|}{$\%$ of Respondents } \\
\hline & $\begin{array}{c}\text { Major } \\
\text { problem }\end{array}$ & $\begin{array}{c}\text { Minor } \\
\text { problem }\end{array}$ & $\begin{array}{c}\text { No } \\
\text { problem }\end{array}$ \\
\hline 1. Tests, assignments and examinations had to be taken in English & 69,12 & 26,47 & 4,41 \\
\hline 2. Learning environment not conducive to effective learning & 54,41 & 29,41 & 16,18 \\
\hline 3. Lack of practical business exposure & 14,49 & 23,19 & 62,32 \\
\hline 4. Ineffective study techniques & 41,17 & 39,71 & 19,12 \\
\hline 5. Fear and anxiety before writing tests/examinations & 45,59 & 35,29 & 19,12 \\
\hline 6. Difficulty in asserting themselves in a predominantly white academic \\
environment & 42,42 & 27,27 & 30,31 \\
\hline 7. No role models in management & 31,82 & 34,85 & 33,33 \\
\hline 8. No mentors in the firm & 25,37 & 38,81 & 35,82 \\
\hline 9. Poor level of training in accountancy at school & 50,82 & 21,31 & 27,87 \\
\hline 10. Poor level of career guidance at school & 27,27 & 22,73 & 50,00 \\
\hline 11. Financial difficulties whilst studying & 34,85 & 37,88 & 27,27 \\
\hline 12. Practical problems (transport, access to computers) & 42,42 & 34,85 & 22,73 \\
\hline 13. Little support from employer with regard to studies & 62,50 & 32,81 & 4,69 \\
\hline
\end{tabular}

A study conducted by Ward et al (1994:267 272) among black students enrolled for Accounting I and II at a predominantly black university and a pre dominantly white university found a pronounced relationship between black students' vocabulary skills and their achievement in accounting. Effective communication and interpretation of information often determines success in the business community. If students cannot master the working vocabulary of business it may adversely affect their progress in accounting classes. Often, also, many black students have not even had minimal opportunities for ex posure to the most basic business or economic experiences.

Memani (1994:25) emphasised the fact that one should remember that for most black people English is not their first, or even their second, language. She suggested perhaps to incorporate a course in com munication skills into the training of black accoun tants who need help in this area. It will enhance self confidence and more fluent expression.

However, in a study conducted among black accoun tants in the USA by Birkett and Prather Stewart (1995:159 171) it was found that "other" activities, such as on the job training, were significantly more helpful in developing students' communication skills and attributes than the classroom. The authors concluded that communication and interpersonal skills are practiced when students participate in professional organisations (such as conducting semi nars and talking to professionals at receptions and dinners) and develop a network of professional relationships. The National Association of Black Accountants' (NABA) in the USA student chapter activities were perceived as being just as useful as the classroom in developing students' leadership and interpersonal skills.

The lack of support from employers with regard to studies was a major problem. This problem should be addressed in the future, because of more and more blacks being allocated bursaries by the "Big 5" firms and the continued assistance of the CAs Eden Trust.

Memani (1994:26 27) questioned the commitment and motivation of auditing firms when employing blacks and establishing training programmes for them. She felt that in some cases the firms appeared to be more concerned with strategically positioning their firm in the market as the profession moves towards the transition period, and with winning goodwill from blacks, than with properly training and developing them. She said that to recruit blacks for the sake of being seen to be associated with them, rather than 
being committed to training them, is an unforgivable $\sin$.

Memani also said that there is a tendency among firms to concentrate only on the top final year black students people who have already overcome huge odds to attain their present level of academic achievement. She suggested that accounting firms consider all levels of black students, and not only the top final year students.

The poor level of training in accountancy at school, which was mentioned by more than 50 per cent as a major problem and by a further 21 per cent as a minor problem, will hopefully be rectified by SAICA's Teachers Enrichment Programme.

There was a highly significant difference on a $99 \%$ confidence level among the sectors of employment as far as role models were concerned. Fifty seven percent of those employed in public practice con sidered a lack of role models in the management of the firm to be a major problem, as against only $20 \%$ of those employed in commerce and industry who thought this to be a major problem.

There was also a highly significant difference again on a 99 per cent confidence level regarding practical factors among respondents who had studied at the different types of universities. It is interesting to note that 61 per cent of those who had completed their graduate studies at a predominantly white university considered practical factors (availability of computers, transport, etc) as a major problem whilst studying, as against the only 28 per cent of those who had studied at a predominantly black university. This could be because the respondents had lived far from the predominantly white universities and that those universities had demanded more from them as far as practical assignments on computers were concerned.

\section{CONCLUSION AND RECOMMENDATIONS}

A number of educational obstacles were identified by black CAs in South Africa in this research project.

More than 50 per cent of the respondents identified the following as major problems whilst studying towards the CA qualification: language problems tests, assignments and examinations had to be written in English; little support from employers with regard to the respondents' studies; learning environment not conducive to effective learning, a poor level of training in accountancy at school.

The respondents were of the opinion that the small number of black CAs could be attributed to the following factors: lack of career guidance (84\%), teachers did not know about the profession (71\%), lack of role models in the profession (59\%), lack of exposure to business (57\%), lack of funding and bursaries (49\%).

Forty percent or more of the respondents mentioned the following reasons, in order of importance, for choosing a career in accounting: prestige of the profession, career prospects, salary potential, intellec tual challenge. The fact that career advisers, parents and family members had played such an insignificant part in them choosing a career in accountancy is indicative of the absence of a positive recruitment effort.

A successful approach to these obstacles should combine the resources of the profession and business, the institutions of higher education, and black CAs themselves.

The profession and business should provide financial support, career guidance and opportunities, role models and study support. Accounting firms should invest heavily in efforts to encourage more blacks to study accounting and should provide more opportu nities for blacks to do their traineeship in the firms. Also, firms should recruit blacks in an aggressive manner and should institute in house programmes in order to retain them. Firms should have blacks in key management positions and more black partners in order to demonstrate that making a commitment to these firms has a real payoff.

The institutions of higher education should provide an appropriate learning environment and supplemen tal financial support, whereas black students can contribute towards their own success by being committed to their studies and by acting as mentors to other aspiring black CAs. This coordinated three party approach would make a significant contribution towards integrating the accounting profession in the real as well as the ideal situation.

The accounting profession can take some pride in what it has achieved in increasing the number of black CAs over the last five years. Let us hope that the next two decades will see such a positive outcome that reality as far as equality is concerned will approach the ideal. At the same time, the black community and educational institutions should re double their efforts to make blacks aware of these opportunities. 


\section{REFERENCES}

Africa News Service 2000. Help wanted: black graduates. 9 January: 5.

Birkett, B S \& Prather Stewart, J 1995. Enhancing students' "professional education" through the National Association of Black Accountants. Issues in Accounting Education Spring 10:159 171.

Cameron, R 1989. Issues in testing bias. College and University Spring:66 73.

Collier, H \& McGowan, C 1989. An empirical examination of the relationship between mathematic skills and course grade in Intermediate Accounting 1. The Accounting Educators Journal Summer:78 86.

Eden Trust 2000. Annual Report:2.

Financial Mail 1999. Special report check mates? 23 April:73 83.

Fontyn, Y 2001. Accountancy: holding on to the skies. Business Day 21 August:6.

Gist, W E, Goodde, H \& Ward B H 1996. The influence of mathematical skills and other factors on minority student performance in principles of accounting. Issues in Accounting Education Spring 11:49 60.

Hammond, T D \& Streeter, D 1994. Overcoming barriers: early African American CPAs. Accounting Organization and Society 19:271 288.

HSRC 1999. SA labour market trends and future workforce needs 1998 2003: labour market analysis.

Lipson, G 2002. Project aims to produce many more black CAs. Sunday Times: Business Times 10 February:5.

Mabena, P 1997. Building for the future. Accountancy SA May:5 11.

Mabena, P 2000. Development of black chartered accountants: progress report. Tema Winter:1 7.

Memani, K 1994. Development of black accountants in the changing SA. Accountancy SA July:25 27.

Mitchell, B N \& Flintall, V L 1990. The status of the black CPA: twenty year update. Journal of Accountancy August:59 67.

Moyes, G D. Williams, P A \& Qurgley, B Z 2000. The relation between perceived treatment discrimination and job satisfaction among African American accounting professionals. American Accounting Association 14:21 48.

Panel Discussion 1999. Is progress being made? Diversity in the accounting profession. The CPA Journal August:15 23.

SAICA 2001. Accountancy Development Unit information session. Johannesburg, 17 May:1 14.

Ward, D R, Wilson, T E \& Ward, S P 1994. A common business and accounting vocabulary base: are black students adequately prepared? Journal of Education for Business 69:267 272 May/June. 